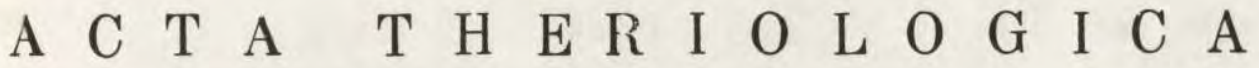 \\ VOL. XIII, 21: $367-389$. \\ BIAEOWIEŻA \\ 30.X.1968
}

Andrzej D R O Ż D Ż

\section{Digestibility and Assimilation of Natural Foods \\ in Small Rodents*)}

[With 1 Fig. \& 7 Tables]

\begin{abstract}
Consumption of natural foods, digestibility, assimilation level, and diurnal energetic requirements were studied in two species of voles (Microtus arvalis, Clethrionomys glareolus) and two species of mice (Apodemus agrarius and Apodemus flavicollis). Eleven concentrated, compound, and bulky diets were examined. For each series 10-15 animals were used. Experiments were carried out in metabolic cages with the aid of the balance method. Coefficients of digestibility for dry matter in concentrated diets (beechmast, acorns, hazel-nuts, oats) reached from $84.3 \%$ up to $93.5 \%$, while in compound diets (hazel-nuts and ground vegetation) from $80.9 \%$ up to $85.5 \%$. Digestibility of dry matter for bulky food was lower in C. glareolus and $M$. arvalis and amounted on an average to $73.9 \%$. Energetic losses in faeces when compared with the energy taken in food fluctuated from 7.1 to 22.6 , while in urine - from 0.7 to $5.4 \%$ depending upon diet. Assimilation level for various foods oscillated within limits from 65.2 to $90.9 \%$ of the energy taken with food. Diurnal energetic requirement calculated from assimilated food amounted to $0.432 \mathrm{kcal} / \mathrm{g} /$ day in C. glareolus, to $0.462 \mathrm{kcal} / \mathrm{g} / \mathrm{day}$ in $M$. arvalis, $0.561 \mathrm{kcal} / \mathrm{g} / \mathrm{day}$ in $A$. agrarius, and to $0.387 \mathrm{kcal} / \mathrm{g} /$ day in $A$. flavicollis.
\end{abstract}

\section{INTRODUCTION}

Studying the energy flow through small rodent population one should investigate what part of the energy taken in food by these animals is assimilated and what part joins the turn over in a form of excretions, i.e. faeces and urine (Davis \& Golley, 1963; Golley, 1967; Petrusewicz, 1967; Petrusewicz \& Ryszkowski, 1967). Thus indispensable becomes the determination of the consumption of natural food, coefficients of digestibility and energy assimilation level. Experiments of this kind, carried out from long ago on farm animals, not only explained relationship between fodder composition and its digestibility and utilization (assimilation), but also shed some light on transformations of energy occuring within animal organism (Brody, 1945; Nehring, 1959; Kle iber, 1961; Blaxter, 1966). Recent nutritional studies on small rodents were

* This study was carried out under the Small Mammal Project of the International Biological Programme in Poland. 
limited exclusively to weight determinations of food consumption ( $\mathrm{S} v$ ir i de $\mathrm{nko}$, 1940; N a umov, 1948; Petrov, 1963; Drożdż, 1964), or to the calculation of food consumption in calories (Morrison \& Teitz, 1953; Górecki \& Gębczyńska, 1962; Grodziński, 1962). More detailed studies were brought to the determination of digestible energy ( $\mathrm{T} \mathrm{urček}, 1956,1957,1967$; G o 11 e y, 1960; Hawkins \& Jewe11, 1962; Odum et al., 1962; Ka c z marski, 1966). The examination of the full energetic balance in small mammals requires still the evaluation of energetic losses with urine. Certain data in this respect were cited only by Golley (1962); Davis \& Golley (l. c.), and Drożd ż (1967).

The present paper concerns mainly digestibility and assimilation of the natural foods in small rodents - voles and mice. It presents also an attempt of the evaluation of diurnal maintenance costs studied on the way of food rations. Owing to this fact it may provide an important element for the construction of energetic balance for these animals.

\section{MATERIAL AND METHODS}

Studies on digestibility and assimilation of natural food were done on four species of rodents: common vole, Microtus arvalis ( $\mathrm{P}$ a 11 a s, 1779), bank vole, Clethrionomys glareolus (S $\mathrm{chreber}, 1780$ ), stripped field mouse, Apodemus agrarius ( $\mathrm{P}$ alla s, 1771), and yellow-necked field mouse, Apodemus flavicollis (M elchior, 1834). These species dominate in our field and forest ecosystems and this is why they were selected for bioenergetic studies under the Polish "Small Mammal Project of IBP«. All animals came from the Ojców National Park near Cracow, where they were captured with the aid of live traps in beech forests, on forest clearings and in fields.

Experiments were done with the balance method, which consists in the daily supplying of animals with a known quantity of food and collection of all faeces and urine. The method determines quantitatively components taken in food and those excreted with faeces and urine. Each series contained $10-15$ adult animals. Altogether the digestibility and assimilation were examined in 120 rodents.

Animals stayed for 14 days on each diet. During the introductory period of 9 days they were kept without litter in metal cages of "Białowieża type $(45 \times$ $25 \times 15 \mathrm{~cm}$ ). At this time they received exclusively test food. The long introductory period not only enabled the complete filling of rodents' alimentary tracts with a new food (Bashenina, 1962; Kostelecka-Myrcha \& Myrcha, 1964), but also their adaptation to the new diet. The proper experimental perind which last five days animals spent in single metabolic cages ${ }^{1}$ ).

These cages were made of rustless sheet and net. They have a form of cylinder $13 \mathrm{~cm}$ high, with a diameter of $12 \mathrm{~cm}$, floor area of $113 \mathrm{~cm}^{2}$ and volume of nearly $1500 \mathrm{~cm}^{3}$. Floor area doubles the standard suggested for laboratory animals with body weight of $20-25 \mathrm{~g}$ ( $\mathrm{L}$ a n e-P e t ter, 1967). Two-part feeder with calibrated diameter of tunnel prevented the carrying out of food and turning of animals in it. Such cages ensured an accurate control of food and water intake, as well as separate collection of faeces and urine (D r o $\dot{z} d \dot{z}, 1968$ ). Animals were weighed before the introductory period, at the beginning and end of proper

1) Voles fed with beechmast provided an exception, since they were kept in two per a cage. 
experiments. All experiments were carried out at the temperature of circa $20 \pm 2^{\circ} \mathrm{C}$ and with 12 hours illumination rhythm.

Natural diets for bank voles and mice were compiled on the base of results of stomach analyses and experiments on food preferences in these rodents (D r o żd ż, 1966, 1967). Food for common voles and stripped field mice were selected on the base of papers by Bashenina (1962) and Holišova (1967). Bank voles were given three types of diets: concentrated, compound, and bulky, common voles - concentrated and bulky one, yellow-necked field mice - two concentrated diets and a compound one, while stripped field mice - only two concentrated diets. Bulky food for mice comprised common plants from forest herb layer: Oxalis acetosella and Galeobdolon luteum ( $\mathrm{R} \mathrm{a} \mathrm{j} \mathrm{ch} \mathrm{e} \mathrm{1,} \mathrm{1965;} \mathrm{K} \mathrm{a} \mathrm{ź-}$ mierczakowa, 1967), which are willingly taken by these rodents (D r o ż d $\dot{z}$, 1966). In the compound diet for bank voles and yellow-necked field mice there was considered only the quantitative ratio of herbaceous plants and seed. This diet corresponded roughly with the mean diet of bank voles and yellow-necked field mice determined from stomach contents. It is composed of milled hazel-nuts (Corylus avellana) and plants (Asperula odorata and Pulmonaria obscura), mixed at the ratio of $3: 1$ of dry matter for bank voles and at the ratio of 10:1 for mice. The concentrated diet for bank voles provided beechmast (Fagus silvatica) and shelled oats, while for yellow-necked field mice - hazel-nuts and acorns (Quercus sessilis). The bulky diet for common voles provided green wheat germinated in laboratory (B a shenina, 1962), while the concentrated one - shelled oats. Stripped field mice were fed with two concentrated diets. Highly caloric compound diet was a modified food given by Grodzińs ki (1962). It was composed of wheat and hazel-nuts mixed at the ratio of $1: 1$. Shelled oats provided another concentrated diet. To prevent the selective feeding on certain components and carrying out food from feeders by animals, mixed food and certain seed were given in a milled state.

Quantitatively collected faeces from metabolic cages were dried in oven, while the urine was acidified with $1 \% \mathrm{H}_{2} \mathrm{SO}_{4}$ and stored in refrigerator at the temperature of $4^{\circ} \mathrm{C}$. Samples of foods, faeces, and urine were subjected to a standard chemical analysis after A. O. A. C. (1960), in which there were determined: dry matter, total protein (Kjeldahl), ether extract (Soxhlet), fibre, N-free extract, and ash. Caloric value of foods, faeces, and urine was determined in calorimetric bomb with Berthelot's method (Górecki, 1965). Caloric value of urine was determined after Nijkamp's method (1965) in the course of burning it with polyethylene foil, on which it was previously vapourized in vacuum oven.

In experiments there were determined: food intake, digestibility of dry matter, organic matter, and digestibility of individual components of food, energetic losses with faeces and urine, assimilation level, as also the daily energetic requirements calculated from assimilated energy.

\section{RESULTS}

\section{Chemical Composition and Caloric Value of Foods, Faeces, and Urine}

Studied foods differed considerably in respect to their chemical composition (Table 1). Concentrated diets (shelled oats, acorns, beechmast, hazel-nuts, wheat + hazel-nuts) were characterized with a very low fibre content, which fluctuated within rather narrow limits from $1.56 \%$ 
Tabela 1.

Chemical composition of food, faeces, and urine expressed in $\% \%$ of dry matter.

\begin{tabular}{|c|c|c|c|c|c|c|c|c|c|}
\hline Diet & $\begin{array}{l}\dot{\varpi} \\
\frac{\tilde{d}}{\pi} \\
3 \\
\dot{0} \\
\text { de }\end{array}$ & $\frac{5}{4}$ & 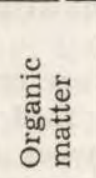 & z & 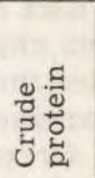 & 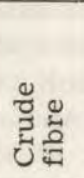 & 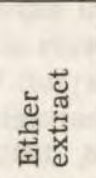 & 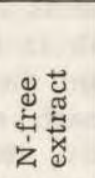 & 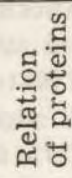 \\
\hline \multicolumn{10}{|c|}{ Microtus arvalis } \\
\hline $\begin{array}{l}\text { Oats } \\
\text { Faeces } \\
\text { Urine }\end{array}$ & 15.0 & $\begin{array}{l}1.71 \\
6.37\end{array}$ & $\begin{array}{l}98.29 \\
93.62\end{array}$ & $\begin{array}{l}1.82 \\
3.81 \\
0.68\end{array}$ & $\begin{array}{l}11.30 \\
23.84\end{array}$ & $\begin{array}{l}1.56 \\
3.01\end{array}$ & $\begin{array}{r}7.36 \\
15.00\end{array}$ & $\begin{array}{l}78.07 \\
51.77\end{array}$ & $1: 9$ \\
\hline $\begin{array}{l}\text { Green wheat } \\
\text { Faeces } \\
\text { Urine }\end{array}$ & 87.60 & $\begin{array}{l}3.11 \\
6.00\end{array}$ & $\begin{array}{l}96.89 \\
94.00\end{array}$ & $\begin{array}{l}3.00 \\
4.24 \\
0.94\end{array}$ & $\begin{array}{l}18.75 \\
26.48\end{array}$ & $\begin{array}{l}27.50 \\
26.73\end{array}$ & $\begin{array}{l}3.08 \\
1.56\end{array}$ & $\begin{array}{l}46.29 \\
40.23\end{array}$ & $1: 5$ \\
\hline \multicolumn{10}{|c|}{ Clethrionomys glareolus } \\
\hline $\begin{array}{l}\text { Beechmast } \\
\text { Faeces } \\
\text { Urine }\end{array}$ & 4.99 & $\begin{array}{r}4.91 \\
21.82\end{array}$ & $\begin{array}{l}95.01 \\
78.06\end{array}$ & $\begin{array}{l}4.88 \\
5.17 \\
2.28\end{array}$ & $\begin{array}{l}30.50 \\
32.35\end{array}$ & $\begin{array}{r}7.25 \\
11.22\end{array}$ & $\begin{array}{l}49.63 \\
24.69\end{array}$ & $\begin{array}{l}7.63 \\
9.92\end{array}$ & $1: 4$ \\
\hline $\begin{array}{l}\text { Mixed } \\
\text { Faeces } \\
\text { Urine }\end{array}$ & 504 & $\begin{array}{l}2.75 \\
7.42\end{array}$ & $\begin{array}{l}97.25 \\
92.58\end{array}$ & $\begin{array}{l}2.73 \\
4.09 \\
1.70\end{array}$ & $\begin{array}{l}17.12 \\
25.58\end{array}$ & $\begin{array}{l}14.84 \\
18.80\end{array}$ & $\begin{array}{r}51.58 \\
8.50\end{array}$ & $\begin{array}{l}13.71 \\
39.70\end{array}$ & $1: 11$ \\
\hline $\begin{array}{l}\text { Oats } \\
\text { Faeces } \\
\text { Urine }\end{array}$ & 15.00 & $\begin{array}{l}1.71 \\
6.85\end{array}$ & $\begin{array}{l}98.29 \\
93.15\end{array}$ & $\begin{array}{l}1.82 \\
3.78 \\
0.75\end{array}$ & $\begin{array}{l}11.30 \\
23.62\end{array}$ & $\begin{array}{l}1.56 \\
3.25\end{array}$ & $\begin{array}{r}7.36 \\
14.25\end{array}$ & $\begin{array}{l}78.07 \\
52.03\end{array}$ & $1: 9$ \\
\hline $\begin{array}{l}\text { Greens } \\
\text { Faeces } \\
\text { Urine }\end{array}$ & 86.20 & $\begin{array}{r}7.85 \\
15.72\end{array}$ & $\begin{array}{l}92.15 \\
84.28\end{array}$ & $\begin{array}{l}2.25 \\
3.18 \\
0.67\end{array}$ & $\begin{array}{l}14.06 \\
10.33\end{array}$ & $\begin{array}{l}33.12 \\
31.25\end{array}$ & $\begin{array}{l}3.15 \\
3.87\end{array}$ & $\begin{array}{l}42.42 \\
38.83\end{array}$ & $1: 6$ \\
\hline \multicolumn{10}{|c|}{ Apodemus agrarius } \\
\hline $\begin{array}{l}\text { Oats } \\
\text { Faeces } \\
\text { Urine }\end{array}$ & 15.00 & $\begin{array}{l}1.71 \\
9.64\end{array}$ & $\begin{array}{l}98.29 \\
90.36\end{array}$ & $\begin{array}{l}1.82 \\
5.59 \\
1.74\end{array}$ & $\begin{array}{l}11.30 \\
34.78\end{array}$ & $\begin{array}{l}1.56 \\
1.93\end{array}$ & $\begin{array}{r}7.36 \\
14.67\end{array}$ & $\begin{array}{l}78.07 \\
38.98\end{array}$ & $1: 9$ \\
\hline $\begin{array}{l}\text { Compound } \\
\text { Faeces } \\
\text { Urine }\end{array}$ & 6.60 & $\begin{array}{l}3.34 \\
8.54\end{array}$ & $\begin{array}{l}97.66 \\
91.45\end{array}$ & $\begin{array}{l}2.02 \\
4.40 \\
3.21\end{array}$ & $\begin{array}{l}12.65 \\
29.92\end{array}$ & $\begin{array}{l}2.65 \\
7.35\end{array}$ & $\begin{array}{r}33.40 \\
7.98\end{array}$ & $\begin{array}{l}51.20 \\
50.75\end{array}$ & $1: 12$ \\
\hline \multicolumn{10}{|c|}{ Apodemus flavicollis } \\
\hline $\begin{array}{l}\text { Hazelnuts } \\
\text { Faeces } \\
\text { Urine }\end{array}$ & 5.35 & $\begin{array}{r}2.38 \\
10.31\end{array}$ & $\begin{array}{l}97.62 \\
89.69\end{array}$ & $\begin{array}{l}2.28 \\
4.93 \\
1.57\end{array}$ & $\begin{array}{l}14.49 \\
26.83\end{array}$ & $\begin{array}{l}2.10 \\
4.48\end{array}$ & $\begin{array}{l}67.14 \\
18.03\end{array}$ & $\begin{array}{l}23.89 \\
40.32\end{array}$ & $1: 14$ \\
\hline $\begin{array}{l}\text { Acorns } \\
\text { Faeces } \\
\text { Urine }\end{array}$ & 14.21 & $\begin{array}{l}2.51 \\
6.24\end{array}$ & $\begin{array}{l}97.49 \\
93.76\end{array}$ & $\begin{array}{l}0.91 \\
1.52 \\
0.57\end{array}$ & $\begin{array}{l}5.74 \\
9.55\end{array}$ & $\begin{array}{l}4.52 \\
8.90\end{array}$ & $\begin{array}{l}6.85 \\
3.40\end{array}$ & $\begin{array}{l}80.36 \\
71.87\end{array}$ & $1: 21$ \\
\hline $\begin{array}{l}\text { Mixed } \\
\text { Faeces } \\
\text { Urine }\end{array}$ & 4.76 & $\begin{array}{r}3.04 \\
10.91\end{array}$ & $\begin{array}{l}96.96 \\
89.09\end{array}$ & $\begin{array}{l}2.46 \\
3.21 \\
0.85\end{array}$ & $\begin{array}{l}15.41 \\
20.07\end{array}$ & $\begin{array}{r}9.39 \\
17.49\end{array}$ & $\begin{array}{l}63.70 \\
20.55\end{array}$ & $\begin{array}{r}8.46 \\
30.98\end{array}$ & $1: 14$ \\
\hline
\end{tabular}


in shelled oats up to $7.25 \%$ in beechmast. These foods differed also in respect to the content of fats, protein, and carbohydrates. Hazel-nuts were of highly fatty character, beechmast - of protein-fatty character, while acorns - carbohydratous one. In mixed diets for voles and mice the content of ether extract was very high and amounted from 51.57 to $63.70 \%$, respectively. The content of total protein was similar in both diets. The higher fibre content in the mixed diet for voles resulted from the higher per cent proportion of plants (ca $30 \%$ ). Bulky diets (green corn, herb layer vegetation) were characterized by a high water content - on an average $85 \%$ and by a very high fibre content -27.5 and $33.1 \%$, respectively.

Table 2.

Caloric value of foods, faeces, and urine. Foods and faeces in $\mathrm{kcal} / \mathrm{g}$ of dry matter free of ash. Urine in $\mathrm{cal} / \mathrm{g}$ of liquid.

\begin{tabular}{|l|c|c|c|}
\hline \multicolumn{1}{|c|}{ Kind of diets } & Food & Faeces & Urine \\
\hline \multicolumn{3}{|c|}{ Microtus arvalis } \\
\hline Oats & 4.389 & 5.280 & 48 \\
Green wheat & 4.836 & 5.486 & 85 \\
\hline \multicolumn{3}{|c|}{ Clethrionomys glareolus } \\
\hline Beechmast \\
Mixed
\end{tabular}

Biological value of food is described by so-called protein ratio or the ratio between digestible protein and digestible components deprived of nitrogen, i. e. N-free extract, fibre and fat (the quantity of fat is multiplied by the coefficient 2.4). Protein ratio of food fluctuated within broad limits from 1:4 in beechmast to not less than 1:21 in acorns (Table 1).

Caloric values of used diets were quite differentiated and were enclosed within limits from $4.159 \mathrm{kcal} / \mathrm{g}$ of ash-free dry weight for 
acorns to $8.032 \mathrm{kcal} / \mathrm{g}$ for hazel-nuts (Table 2). Since the caloric value of diet is dependent mainly upon its fat content, thus caloric values of fat-protein diets (nuts, beechmast, mixed diets) were highest and fluctuated from about $6,000 \mathrm{kcal} / \mathrm{g}$ to more than $8,000 \mathrm{kcal} / \mathrm{g}$; on the other hand bulky diets (green corn and herb layer vegetation) and concentrated diets with carbohydratous and carbohydratous-protein character (acorns, oats) did not exceed $5,000 \mathrm{kcal} / \mathrm{g}$ (Table 2).

Energetic values of faeces and urine obtained from rodents fed with various diets were very similar for $1 \mathrm{~g}$ of dry faeces $(4,690 \mathrm{kcal}-5,486$ $\mathrm{kcal}$ ), while for $1 \mathrm{~g}$ of liquid urine were contained within very broad limits from 48 to $331 \mathrm{cal} / \mathrm{g}$. The lower caloric value of urine was found in common and bank voles fed with bulky diet, while the higher one in mice (Table 2).

\section{Digestibility of Natural Food}

All test diets were characterized with high coefficients of digestibility for individual components, what evidenced their high utilization. The digestibility of more important components - total protein, fat, and fibre oscillated most frequently within limits of $70-90 \%$ (Table 3). The greatest range between coefficients of digestibility for various diets has been found in common voles. The highest coefficient of digestibility for dry matter and organic substance was found in common voles fed with shelled oats. The coefficient of digestibility amounted to not less than $93.54 \%$ for dry matter, while to $94.02 \%$ for organic matter. The digestibility of bulky diet was by almost $20 \%$ lower in the same rodent species.

Coefficients of digestibility for dry matter and organic matter for diets fed to bank voles were also very high. They fluctuated from 80 to $90 \%$, except of compound diet from herb layer vegetation, the digestibility of which was distincly lower (Table 3 ).

Mice digested their diets to a high extent. Coefficients of digestibility for the dry matter of these diets fluctuated from 82.3 up to $91.7 \%$, while for organic substances - from 82.8 to $92.1 \%$ (Table 3 ).

The value of coefficients of digestibility for dry matter and organic substances in the studied rodents depends mainly upon fibre content in diet (compare table 1 and table 3). Results obtained with acorns provided an exception. Slightly lower digestibility of this diet is probably connected with its very broad protein ratio and low moisture content. The relationship between the increase in fibre content and the lowering of digestibility coefficient is distincly visible. Diets with low fibre content - shelled oats, hazel-nuts, beechmast amounting from 
1.56 to $2.10 \%$, are easily digestible (about 88 to $93.5 \%$ ), while diets with high fibre content from 15 up to $33.12 \%$ - green corn, herb layer vegetation, compound diet for voles have distincly lower coefficient of digestibility (circa 74 to $80 \%$ ). There were found no fundamental differences in possibilities of digestion of these same diets in studied rodent species. Both the common vole and mice have similar coefficients

Tabela 3.

Coefficients of digestibility for individual food components expressed in per cents of component's intake (means for 10-15 animals).

\begin{tabular}{|c|c|c|c|c|c|c|}
\hline Kind of diet & $\begin{array}{c}\text { Dry } \\
\text { matter }\end{array}$ & $\begin{array}{l}\text { Organic } \\
\text { matter }\end{array}$ & $\begin{array}{l}\text { Crude } \\
\text { protein }\end{array}$ & $\begin{array}{l}\text { Ether } \\
\text { extract }\end{array}$ & $\begin{array}{l}\text { Crude } \\
\text { fibre }\end{array}$ & $\begin{array}{l}\mathrm{N} \text {-free } \\
\text { extract }\end{array}$ \\
\hline \multicolumn{7}{|c|}{ Microtus arvalis } \\
\hline $\begin{array}{l}\text { Oats } \\
\text { Green wheat }\end{array}$ & $\begin{array}{l}93.54 \\
73.94\end{array}$ & $\begin{array}{l}94.02 \\
74.49\end{array}$ & $\begin{array}{l}86.37 \\
63.20\end{array}$ & $\begin{array}{l}86.95 \\
87.01\end{array}$ & $\begin{array}{l}87.82 \\
74.69\end{array}$ & $\begin{array}{l}95.72 \\
77.36\end{array}$ \\
\hline \multicolumn{7}{|c|}{ Clethrionomys glareolus } \\
\hline Beechmast & 88.17 & 90.15 & 87.47 & 94.11 & 81.79 & 84.66 \\
\hline Mixed & 80.98 & 82.85 & 71.61 & 96.87 & 81.26 & 44.93 \\
\hline Oats & 89.75 & 90.69 & 78.58 & 80.16 & 66.02 & 93.23 \\
\hline Greens & 74.01 & 75.82 & 82.29 & 70.47 & 77.20 & 92.40 \\
\hline \multicolumn{7}{|c|}{ Apodemus agrarius } \\
\hline Oats & 91.70 & 92.13 & 74.51 & 83.55 & 89.74 & 95.86 \\
\hline Compound & 85.45 & 86.76 & 65.61 & 97.24 & 68.30 & 85.58 \\
\hline \multicolumn{7}{|c|}{ Apodemus flavicollis } \\
\hline Hazelnuts & 88.95 & 89.53 & 79.57 & 97.03 & 76.66 & 67.96 \\
\hline Acorns & 82.31 & 82.82 & 70.73 & 91.24 & 65.26 & 84.18 \\
\hline Mixed & 85.55 & 86.65 & 81.18 & 95.35 & 73.16 & 47.16 \\
\hline
\end{tabular}

of digestibility on the same diets. For example the digestibility of oats in bank voles, common voles, and stripped field mice fluctuated within limits of $4 \%$, namely from about 90 up to $93.5 \%$ (Table 3 ).

\section{Energetic Losses with Faeces and Urine}

The energy taken in food is obwiously not completely utilized by animals. A portion of it leaves organisms with a not fully digested diet in a form of faeces, and another portion goes with not completely degraded compounds of nitrogen in urine. The size of these losses depends not only on the quantity of excrements, but also on their caloric value. Losses of energy contained in faeces and urine expressed in per 
cent of energy taken (gross energy) usually deviate only slightly from losses calculated in per cents of dry weight (Table 3 and 4). Common voles fed with the concentrated diet - shelled oats, excreted with faeces and urine on an average $10 \%$ of the value of energy of food uptake, what evidences a very intensive utilization of the energy taken. On the other hand when fed with bulky diet they lost in faeces and urine not less than $35 \%$ of the energy contained in diet. In bank voles

Tabela 4.

Digestibility and assimilation of natural foods of common voles, bank voles, and mice (in per cents of energy intake). Means \pm standard deviations are given.

\begin{tabular}{|c|c|c|c|c|c|}
\hline Diet & $\begin{array}{l}\text { Number } \\
\text { of animals }\end{array}$ & Faeces & $\begin{array}{c}\text { Digested } \\
\text { energy }\end{array}$ & Urine & $\begin{array}{c}\text { Assimilated } \\
\text { energy }\end{array}$ \\
\hline \multicolumn{6}{|c|}{ Microtus arvalis } \\
\hline Oats & 10 & $7.68+1.51$ & $92.32+1.37$ & $2.60+1.21$ & $89.72+0.94$ \\
\hline Green wheat & 10 & $29.61 \pm 1.61$ & $70.39 \pm 1.55$ & $5.15 \pm 0.66$ & $65.24 \pm 1.10$ \\
\hline \multicolumn{6}{|c|}{ Clethrionomys glareolus } \\
\hline Beechmast & 10 & $7.14 \pm 1.41$ & $92.86 \pm 1.29$ & $4.15+0,55$ & $88.71 \pm 1.42$ \\
\hline Mixed & 10 & $12.22 \pm 1.45$ & $87.78 \mp 1.38$ & $2.97 \mp 1.62$ & $84.81 \mp 1.48$ \\
\hline Oats & 10 & $10.89 \mp 2.25$ & $89.11 \pm 2.24$ & $2,99 \pm 1.15$ & $86.12 \mp 2.30$ \\
\hline Greens & 10 & $22.59 \pm 2.69$ & $77.41 \pm 3.48$ & $5.40 \pm 0.74$ & $72.02 \pm 3.51$ \\
\hline \multicolumn{6}{|c|}{ Apodemus agrarius } \\
\hline Oats & 15 & $9.55 \pm 0.65$ & $90.45 \pm 1.15$ & $1.44 \pm 0.91$ & $89.01 \pm 1.11$ \\
\hline Compound & 10 & $10.38 \pm 1.74$ & $89.62 \pm 1.38$ & $0.73 \pm 0.18$ & $88.89 \pm 1.51$ \\
\hline \multicolumn{6}{|c|}{ Apodemus flavicollis } \\
\hline Hazelnuts & 11 & $7.78 \div 1.21$ & $92.22 \pm 0.95$ & $1.27 \pm 0.45$ & $90.95 \pm 1.02$ \\
\hline Acorns & 12 & $18.61 \pm 1.25$ & $81.39 \mp 1.58$ & $2.67 \mp 0.65$ & $78.72 \mp 1.55$ \\
\hline Mixed & 11 & $8.91 \pm 0.55$ & $91.09 \pm 0.53$ & $2.53 \pm 1.65$ & $88.56 \pm 0.67$ \\
\hline
\end{tabular}

kept on concentrated and compound diets energetic losses with faeces fluctuated from 7 up to $12 \%$, while those with urine from circa 3 to $4 \%$. Bulky food (herb layer vegetation) was utilized at worst similarly as in common voles. Energetic losses with excrements amounted to $28 \%$, thus assimilated energy reached only $72 \%$. A. agrarius revealed a very similar degree of the utilization of both served diets, Both those fed with shelled oats and with highly caloric compound diet assimilated $89 \%$ of the energy taken in food. A. flavicollis also digested and assimilated almost $90 \%$ from diets served to them. Exception provided acorns, from which rodents were able to assimilate only $78.7 \%$ of energy (Table 4). 


\section{Diurnal Intake and Assimilation of Energy}

Diurnal energy intake by rodents depended upon the type of diet, its caloric value, and also upon the size of animal itself. Rodents consumed daily on average from about 2 up to $4 \mathrm{~g}$ of highly caloric food and not less than 18 to $25 \mathrm{~g}$ of bulky food. Caloric values of taken food fluctuated from circa 12 to $16 \mathrm{kcal}$ (Table 5).

\section{Tabela 5 .}

Daily consumption and assimilation of foods by common voles, bank voles, and mice (means for 10-15 animals \pm standard deviations).

\begin{tabular}{|c|c|c|c|c|}
\hline Diet & $\begin{array}{c}\text { Average body } \\
\text { weight }(\mathrm{g})\end{array}$ & $\underset{(\mathrm{g})}{\text { Consumption }}$ & $\begin{array}{c}\text { Consumption } \\
\text { (kcal) }\end{array}$ & $\begin{array}{c}\text { Assimilation } \\
\text { (kcal) }\end{array}$ \\
\hline \multicolumn{5}{|c|}{ Microtus arvalis } \\
\hline $\begin{array}{l}\text { Oats } \\
\text { Green wheat }\end{array}$ & $\begin{array}{l}22.6 \pm 2.2 \\
21.8 \pm 2.1\end{array}$ & $\begin{array}{r}4.24 \pm 0.73 \\
25.00 \pm 1.41\end{array}$ & $\begin{array}{l}16.20 \pm 2.81 \\
15.01 \pm 0.85\end{array}$ & $\begin{array}{r}14.52 \pm 2.01 \\
9.80 \pm 0.75\end{array}$ \\
\hline \multicolumn{5}{|c|}{ Clethrionomys glareolus } \\
\hline $\begin{array}{l}\text { Beechmast } \\
\text { Mixed } \\
\text { Oats } \\
\text { Greens }\end{array}$ & $\begin{array}{l}22.7 \pm 2.6 \\
23.1 \pm 2.1 \\
22.9 \pm 2.0 \\
22.4 \pm 3.6\end{array}$ & $\begin{array}{r}1.92 \pm 0.25 \\
2.26 \pm 0.30 \\
3.40 \pm 0.48 \\
18.26 \pm 2.90\end{array}$ & $\begin{array}{l}13.25 \pm 1.73 \\
25.18 \pm 2.05 \\
13.01 \pm 1.85 \\
12.75 \pm 2.07\end{array}$ & $\begin{array}{r}11.79 \pm 1.73 \\
12.90 \pm 2.03 \\
11.20 \pm 1.87 \\
9.23 \pm 1.88\end{array}$ \\
\hline \multicolumn{5}{|c|}{ Apodemus agrarius } \\
\hline $\begin{array}{l}\text { Oats } \\
\text { Compound }\end{array}$ & $\begin{array}{l}22.3 \pm 1.6 \\
20.6 \pm 2.2\end{array}$ & $\begin{array}{l}3.46 \pm 0.53 \\
3.00 \pm 0.25\end{array}$ & $\begin{array}{l}13.24 \pm 2.06 \\
16.92 \pm 1.45\end{array}$ & $\begin{array}{l}11.78 \pm 1.12 \\
15.04 \pm 0.81\end{array}$ \\
\hline \multicolumn{5}{|c|}{ Apodemus flavicollis } \\
\hline $\begin{array}{l}\text { Hazelnuts } \\
\text { Acorns } \\
\text { Mixed }\end{array}$ & $\begin{array}{l}27.9 \pm 4.1 \\
24.1 \pm 3.2 \\
28.8 \pm 5.5\end{array}$ & $\begin{array}{l}2.12 \pm 0.33 \\
3.50 \mp 0.55 \\
2.06 \pm 0.31\end{array}$ & $\begin{array}{l}16.28 \pm 2.56 \\
12.78 \pm 1.95 \\
14.66 \pm 2.92\end{array}$ & $\begin{array}{l}14.84 \div 1.91 \\
10.07 \pm 1.55 \\
12.98 \pm 2.01\end{array}$ \\
\hline
\end{tabular}

Daily energetic losses with faeces and urine in rodents fed with various diets amounted on an average to $3.44 \mathrm{kcal}$ for $M$. arvalis, 2.26 kcal for C. glareolus, $1.67 \mathrm{kcal}$ for A. agrarius, and $1.94 \mathrm{kcal}$ for A. flavicolis.

\section{Nitrogen Balance}

Table 6 presents results of the study on nitrogen metabolism in rodents fed with various diets during 5 days long experimental period. Common voles, for example, fed with shelled oats consumed on an average $0.33 \mathrm{~g}$ of $\mathrm{N}$ with food, excreted $0.04 \mathrm{~g}$ with faeces, and $0.28 \mathrm{~g}$ with urine. With bulky food in spite of fact that they consumed $0.46 \mathrm{~g}$ of $\mathrm{N}$, due to the low digestibility of this diet (Table 3 ) they excreted 
not less than $0.17 \mathrm{~g}$ of $\mathrm{N}$ with feaces. The metabolism of nitrogen in voles fed with various diets was rather similar. Voles excreted on an average $0.06 \mathrm{~g}$ of $\mathrm{N}$ with faeces, while $0.27 \mathrm{~g}$ of $\mathrm{N}$ with urine. There was found a negative nitrogen balance for compound and bulky diets. For stripped field mice on both diets the nitrogen balance was negative, while for yellow-necked field mice it was negative only in the case of feeding with acorns.

Tabela 6.

Nitrogen balance - mean values for one animal during the period of five days of experiment.

\begin{tabular}{|c|c|c|c|c|c|}
\hline Diet & $\begin{array}{l}\mathrm{N} \text { in food } \\
(\mathrm{g})\end{array}$ & $\underset{\text { (g) }}{N \text { in faeces }}$ & $\begin{array}{c}N \text { digested } \\
(\mathrm{g})\end{array}$ & $\underset{(\mathrm{g})}{\mathrm{N}}$ in urine & $\begin{array}{c}\text { Balance } \\
(\mathrm{g})\end{array}$ \\
\hline \multicolumn{6}{|c|}{ Microtus arvalis } \\
\hline $\begin{array}{l}\text { Oats } \\
\text { Green wheat }\end{array}$ & $\begin{array}{l}0.33 \\
0.46 \\
\end{array}$ & $\begin{array}{l}0.04 \\
0.17\end{array}$ & $\begin{array}{l}0.29 \\
0.29\end{array}$ & $\begin{array}{l}0.28 \\
0.32\end{array}$ & $\begin{array}{r}0.01 \\
-0.03\end{array}$ \\
\hline \multicolumn{6}{|c|}{ Clethrionomys glareolus } \\
\hline $\begin{array}{l}\text { Beechmast } \\
\text { Mixed } \\
\text { Oats } \\
\text { Greens }\end{array}$ & $\begin{array}{l}0.44 \\
0.29 \\
0.27 \\
0.33\end{array}$ & $\begin{array}{l}0.06 \\
0.08 \\
0.06 \\
0.06\end{array}$ & $\begin{array}{l}0.38 \\
0.21 \\
0.21 \\
0.27\end{array}$ & $\begin{array}{l}0.36 \\
0.23 \\
0.18 \\
0.32\end{array}$ & $\begin{array}{r}0.02 \\
-0.02 \\
0.03 \\
-0.05\end{array}$ \\
\hline \multicolumn{6}{|c|}{ Apodemus agrarius } \\
\hline $\begin{array}{l}\text { Oats } \\
\text { Compound }\end{array}$ & $\begin{array}{l}0.27 \\
0.28\end{array}$ & $\begin{array}{l}0.07 \\
0.09\end{array}$ & $\begin{array}{l}0.20 \\
0.19\end{array}$ & $\begin{array}{l}0.26 \\
0.22\end{array}$ & $\begin{array}{l}-0.06 \\
-0.03\end{array}$ \\
\hline \multicolumn{6}{|c|}{ Apodemus flavicollis } \\
\hline $\begin{array}{l}\text { Hazelnuts } \\
\text { Acorns } \\
\text { Mixed }\end{array}$ & $\begin{array}{l}0.23 \\
0.14 \\
0.24\end{array}$ & $\begin{array}{l}0.05 \\
0.04 \\
0.04\end{array}$ & $\begin{array}{l}0.18 \\
0.10 \\
0.20\end{array}$ & $\begin{array}{l}0.17 \\
0.12 \\
0.14\end{array}$ & $\begin{array}{r}0.01 \\
-0.02 \\
0.06\end{array}$ \\
\hline
\end{tabular}

An adult rodent with body weight of $25 \mathrm{~g}$ took daily with food on an average $0.06 \mathrm{~g}$ of $\mathrm{N}$, out of which it excreted with faeces $0.01 \mathrm{~g}$, while with urine $0.05 \mathrm{~g}$ of $\mathrm{N}$.

\section{Determination of Maintenance Costs}

Daily maintenance costs in rodents were calculated from metabolizable energy of consumed diets (Table 7). One should remember that the value of metabolizable energy depends upon food intake, coefficient of digestibility, and energetic losses with excreted urine.

In $M$. arvalis fed with oats the metabolizable energy amounted on average to $0.641 \mathrm{kcal} / \mathrm{g} /$ day and permitted them not only to meet 
maintenance costs, but also for the production of body. During five days long experiment all examined animals gained on an average by $0.6 \mathrm{~g}$. On the other hand, when fed with green corn they were not capable to meet their energetic requirements. Metabolizable energy of green corn at the rate of $0.450 \mathrm{kcal} / \mathrm{g} /$ day was insufficient for maintaining the constant body weight. During experiment animals lost on average $1.1 \mathrm{~g}$. Bank voles fed with beechmast and compound diet gained

Tabela 7.

Daily energetic requirements in rodents calculated from assimilated energy.

\begin{tabular}{|c|c|c|c|c|c|c|c|}
\hline Diet & $\begin{array}{l}\text { Body } \\
\text { weight } \\
\text { (g) }\end{array}$ & 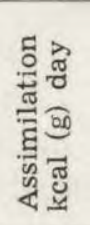 & 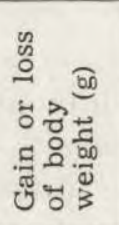 & 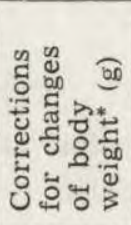 & 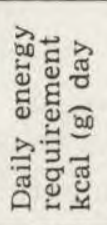 & 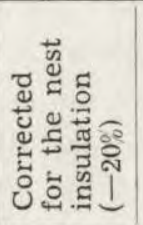 & 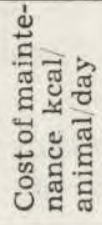 \\
\hline \multicolumn{8}{|c|}{ Microtus arvalis } \\
\hline Oats & 22.6 & 0.641 & +0.6 & -0.057 & 0.584 & 0.467 & 10.55 \\
\hline \multirow{2}{*}{\multicolumn{8}{|c|}{ Clethrionomys glareolus }} \\
\hline & & & & & & & \\
\hline Beechmast & 22.7 & 0.519 & +0.6 & -0.057 & 0.462 & $0.462^{* *}$ & 10.48 \\
\hline Mixed & 23.1 & 0.558 & +0.2 & 0 & 0.558 & 0.446 & 10.12 \\
\hline Oats & 22.9 & 0.489 & -0.5 & +0.039 & 0.528 & 0.422 & 9.66 \\
\hline Greens & 23.4 & 0.392 & -1.8 & +0.110 & 0.502 & 0.401 & 9.38 \\
\hline \multicolumn{8}{|c|}{ Apodemus agrarius } \\
\hline Oats & 22.3 & 0.555 & -2.1 & +0.105 & 0.660 & 0.528 & 11.77 \\
\hline Compound & 20.6 & 0.743 & -0.2 & 0 & 0.743 & 0.594 & 12.23 \\
\hline \multicolumn{8}{|c|}{ Apodemus flavicollis } \\
\hline Hazelnuts & 27.9 & 0.540 & +0.8 & -0.059 & 0.481 & 0.384 & 10.71 \\
\hline Acorns & 24.1 & 0.433 & -1.2 & -0.054 & 0.487 & 0.389 & 9.37 \\
\hline Mixed & 28.6 & 0.465 & -0.7 & +0.023 & 0.488 & 0.390 & 11.15 \\
\hline
\end{tabular}

* For more detailed explanations see text on page 383 . ** The effect of lack of nest was not detracted - animals stayed by two in a cage.

on weight on an average from 0.2 to $0.6 \mathrm{~g}$, thus the provided metabolizable energy fluctuating from 0.519 to $0.558 \mathrm{kcal} / \mathrm{g} /$ day exceeded slightly their maintenance requirements. In bank voles fed exclusively with greenstuff, similarly as in common voles, there occurred a considerable drop in body weight, on an average by $1.8 \mathrm{~g}$. The metabolizable energy at the rate of $0.392 \mathrm{kcal} / \mathrm{g} /$ day is thus too low for a bank vole to meet its maintenance costs. Stripped field mice have 
slightly higher energetic requirements, than the above discussed species. When fed with oats they revealed a remarkable drop in body weight (on an average by $2.1 \mathrm{~g}$ ), in spite of fact that the metabolizable energy at their disposal was relatively high and amounted to $0.555 \mathrm{kcal} / \mathrm{g} / \mathrm{day}$. On the other hand, when fed with highly caloric compound diet they maintained a constant body weight taking not less than $0.743 \mathrm{kcal} / \mathrm{g} /$ day of metabolizable energy. When compared with A. agrarius, which are larger, A. flavicollis are characterized with slightly lower maintenance costs. When fed with hazel-nuts they gained slightly, while having at disposal $0.540 \mathrm{kcal} / \mathrm{g} / \mathrm{day}$, and when fed with acorns and mixed food they were loosing when provided with 0.433 and $0.465 \mathrm{kcal} / \mathrm{g} /$ day of metabolizable energy.

In the calculation of actual maintenance costs there were taken into consideration allowances for changes in animal body weight in the course of experiment. Estimated thus actual maintenance costs for rodents staying in metabolic cages become ever more similar in spite of the use of various diets and various nutrition levels (Table 7). Energetic requirement of various rodent species is negatively correlated with their body size. And so in the smallest stripped field mouse it was the highest and amounted on average to $0.701 \mathrm{kcal} / \mathrm{g} /$ day, for common voles it amounted to $0.577 \mathrm{kcal} / \mathrm{g} /$ day, while for bank voles to $0.512 \mathrm{kcal} / \mathrm{g} /$ day. On the other hand, in largest yellow-necked field mouse it is the lowest and reached only $0.485 \mathrm{kcal} / \mathrm{g} /$ day.

\section{DISCUSSION}

\section{Consumption, Digestibility, and Assimilation of Foods}

In order to answer the question put forward in the introduction, namely what part of energy taken in food is assimilated and what part returns to circulation in a form of faeces, there were carried out nutritional experiments on digestibility in which rodents were fed with natural foods. The arrangement of such diets is not easy, since the food of rodents reveals seasonal variation. For example forest rodents (C. glareolus, A. flavicollis) in autumn and winter feed mainly on tree seed, during spring and summer on the other hand consume mixed food (Droz d $\dot{z}, 1966)$. The diet of field rodents ( $M$. arvalis, A. agrarius) is also more concentrated during autumn and winter (B a shenina, 1962; Holišova, 1967). The selection of diets has thus to consider not only food habits of rodents, studied on the way of food preferences and stomach analyses by $\mathrm{Naumov}$ (1948), Koškina (1957), Miller (1954), Holišova (1960), Górecki \& Gę bczyń- 
ska (1962), Petrov (1963), D rożd ż (1966), but also the distinct structure of their alimentary tracts (Grodzinski, 1962; Myrcha, 1964; 1965; V o r o ntsov, 1967). Hence in experiments rodents were given concentrated, mixed, and bulky diets, which approximately corresponded with various, seasonal foods of rodents in nature. Diets for voles differed fundamentally from those given to field mice.

Nutritional experiments, in which the quantity of consumed by rodents food was determined exclusively by weight, are entirely useless for bioenergetic purposes due to the complete incomparability of obtained results (various caloric values of provided foods). The calculation of food intake in calories yields more comparable results, especially when converted into $1 \mathrm{~g}$ of animal body weight. Such data for the discussed rodents were compiled by $\mathrm{T}$ anton (1965) and they almost completely are enclosed within 0.32 and $0.96 \mathrm{kcal} / \mathrm{g} /$ day. The further step in accuracy is achieved through the determination of digested energy, i.e. after the deduction of energetic values of faeces. Turč e k $(1956,1957)$ estimated the digestible energy on $0.639 \mathrm{kcal} / \mathrm{g} /$ day for yellow-necked field mice fed with acorns, while $\mathrm{Kaczmarski}$ (1966) on $0.704 \mathrm{kcal} / \mathrm{g} /$ day for voles fed with wheat and carrot. According to $\mathrm{Od} \mathrm{u} \mathrm{m}$ et al. (1962) maintenance costs for Peromyscus polionotus amounted to $0.61 \mathrm{kcal} / \mathrm{g} /$ day. The determination of maintenance costs from metabolizable energy (D r o żd ż, 1967, 1968) provides the method which gives most comparable results. Energetic losses with faeces and urine are strictly connected with diet composition and digestibility. For example caloric values for faeces obtained from various rodents fed with husked oats are very similar. On the other hand there was found no correlation between the caloric value of food and that of faeces.

Golley (1960) estimated energetic losses with faeces in Microtus pennsylvanicus fed with alfalfa on $10 \%$, while in those fed with a mixed diet (carrot, lettuce, and oatmeal) - on 18\%. For Peromyscus polionotus and Sigmodon hispidus fed with various plants the energy excreted with faeces has been estimated on 8 to $36 \%$ in relation to the diet in use, Golley, 1962). Turček (1956) during his 10 days long experiment found that yellow-necked field mice fed with acorns excreted in faeces only $10 \%$ of the energy taken. These data are slightly lower, than those obtained in the present work and estimated on $18.6 \%$. K a c z marski (1966), while feeding bank voles with wheat and carrot indicated that energetic losses with faeces amounted to only $11.5 \%$.

Data concerning energetic values of urine in wild rodents are still very scarce. It results from the present work and also from experiments with laboratory mice and rats that losses with urine do not exceed $5 \%$ 
of energy taken (Davis \& Golley, 1963; Trela, 1964). Caloric value of urine from examined voles and mice was similar to that in farm animals ( $\mathrm{Nehring,1959).} \mathrm{In} \mathrm{common} \mathrm{and} \mathrm{bank} \mathrm{voles} \mathrm{fed} \mathrm{with}$ bulky food there was found a distincly lower energetic value of urine. This is connected with the quantity od daily consumed water and axcreted urine. Common and bank voles excrete daily from from 8 up to $15 \mathrm{~g}$ urine, while stripped field mice - only $2-3 \mathrm{~g}$.

Animal excrements are utilized in the circulation of matter in the course of the formation of a new primary production. Rodents excrete daily from 0.22 up to $0.81 \mathrm{~g}$ of dry matter of faeces in relation to diet. One may assume that both forest and field rodents excrete daily on average circa $0.40 \mathrm{~g}$ of dry matter of faeces, therefore one rodent produces during a years about $150 \mathrm{~g}$ of faeces with a caloric value of circa $688 \mathrm{kcal} / \mathrm{g} /$ dry matter. This is twenty times more, than the caloric value of its body with the weight of $25 \mathrm{~g}$ (G ó r e ck i, 1965). Steppe rodents in Eurasia zone for example, might produce from 20 up to $250 \mathrm{~kg}$ of air dry faeces per hectare annually in relation to their density, what presents already an important item in the circulation of energy ( $\mathrm{K} \mathrm{u}$ č e r u k, 1963). The richness of mineral compounds returned to circulation is also of importance. In the present experiment rodent's faeces contained from 6 up to $21.8 \%$ of mineral substances depending upon diet (Table 1). The determination of their quality provides a very important stage in studies on the circulation of elements, compounds and transformations of energy in nature ( $\mathrm{D}$ a v is \& G o ll e y, 1963; R a f e s et al., 1964).

Digestibility of diets depends mainly upon their chemical composition. The digestibility of dry matter for concentrated diets was very high in rodents and amounted on the average to $89.07 \%$ (Table 3 ). High digestibility of these diets is connected, among others, with their low fibre content (Table 1). Owing to the low per cent of water they have always the higher caloric value, than bulky food and therefore are consumed in smaller quantities. For example, the bank vole according to Grodziński (1962) consumed $2.88 \mathrm{~cm}^{3}$ of concentrated diet, while not less than $29.21 \mathrm{~cm}^{3}$ of bulky diet. Small amount of food is for longer time retained within alimentary tract and therefore is utilized better (B a shenina, 1962; Grodziński, l. c.; Myrcha, 1964).

The low digestibility of bulky food is connected with three factors: (1) high fibre content, which in served food amounted to $25-33 \%$,

(2) high rate passage of these foods through alimentary tract, and

(3) decrease in digestion effects with the consumption of excessive quantities of food. It is known that fibre content very obviously affects 
the lowering of coefficients of digestibility. The distinct correlation between fibre content and digestibility permitted A xels on (after $\mathrm{Neh}$ $\mathrm{ring}$, 1959) to develop regression equations determining the rate of digestibility decrease along with the increasing content of fibre in diet. $\mathrm{Nehring}$ (1965) claims that the increase of fibre in food by $1 \%$ results in the decrease in digestibility by 0.6 unit in ruminants and by 2 units in rodents. Fibre presents the fraction of food which contains

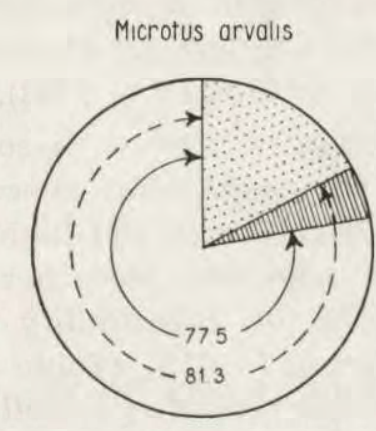

Clethrionomys glareolus

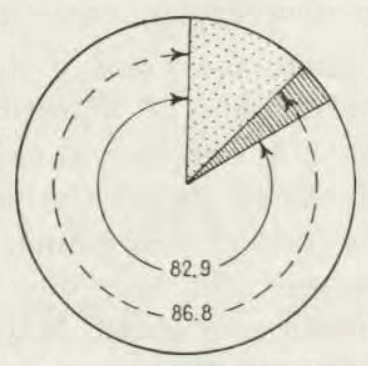

Apodemus agrarius

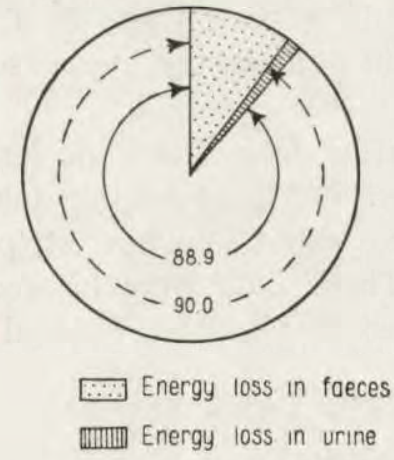

Apodemus flavicollis

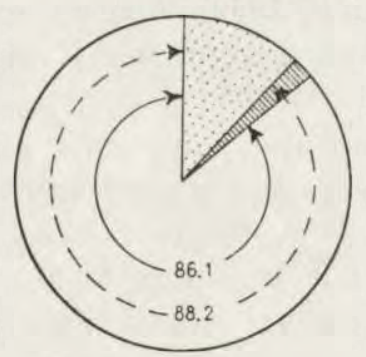

- - Digested energy

Metabolizable energy

Fig. 1. Average coefficients of digestibility for all used natural diets in small rodents (in percentage of the energy intake).

such hardly digestible or undigestible components as cellulose, pentosans, cutin, lignine frequently incrusted with mineral salts. This provides the ballast of food, which when given in excess may cause the lowering of digestibility for all food components. Common and bank voles have well developed caecum (V or ontsov, 1967) and hence some quantities of fibre have to occur in their diets. Higher fluctuations in digestibility are noted when animals are fed with foods with high 
fibre content. This is evidenced by greater standard deviations for these diets (Table 4).

While feeding rodents with bulky food one can note a very rapid passage of food content through alimentary tract. According to B ashenina (1962) common voles fed with greenstuff may excrete the food taken already after one hour. They cannot obviously be subjected to a thorough digestion during such a short time. Common and bank voles fed with greens consumed on average $25 \mathrm{~g}$ of fresh weight. Such an enormous quantity of food results in the overloading of alimentary tract and decrease in digestibility (D a v is \& Golley, 1963).

Mixed diets for voles and mice were characterized with somewhat lower coefficients of digestibility, when compared with concentrated diets (Table 3 ). In this case it is connected also with the higher fibre content in these diets. The source of fibre provided here herb layer vegetation mixed hazel-nuts. The coefficient of digestibility in dry weight mixed diet for voles amounted almost to $81 \%$ (Table 3) with fibre content of about $15 \%$ (Table 1), while for A. flavicollis - to about $85 \%$ with fibre content of $9 \%$. There was noted no effect of fat content upon the digestibility of diets.

The low digestibility of acorns results probably from their very broad protein ratio $(1: 21)$, what sometimes involves the decline in digestibility (N e hring, 1959). Acorns served were drier than those in T u r č ek's (1956) experiments, what might also influenced the decrease in digestibility.

Common and bank voles obviously differ from both species of mice. On an average common voles assimilated $77.5 \%$ of energy taken, bank voles $-83 \%$, yellow-necked field mice $-86.1 \%$, while stripped field mice - not less than $88.9 \%$ (Fig. 1). These data may be accepted as average annual coefficients of the assimilation for natural foods of rodents under natural conditions.

\section{Maintenance Costs}

In estimating daily maintenance costs of animals ecologists successfully use the techniques of food rations. The method consists in the determination of daily energy intake in food by animal $(C)$ and on the determination of metabolizable energy $(A)$ by the detraction of energetic values of faeces $(F)$ and urine $(U)$.

$$
A=\mathrm{C}-\mathrm{FU}
$$

With food for maintenance (Nehring, 1959; Blaxter, 1966) on which animal does not change its body weight (production $=0$ ) the 
metabolizable energy is utilized completely on maintenance costs in the process of respiration.

$$
A=R(P=0)
$$

Therefore maintenance costs calculated from the consumed metabolizable energy might be compared with the respiration measured by oxygen consumption as so-called average daily metabolism rate ADMR (G ę b czyński, 1966; Grodziński, 1966; Grodziński \& Górecki, 1967) or as the resting metabolism rate - RMR (G r odziński, 1961; Górecki, 1966). Both these metabolism rates $\left(A D M R\right.$ and $R M R$ ) measured at $20^{\circ} \mathrm{C}$ provide basis for the construction of daily energetic budgets for rodents ( $\mathrm{Grodzinski} \mathrm{\&} \mathrm{Gó-}$ recki, l.c.). Such temperature prevails in natural nests of rodents and is close also to the thermopreferendum of the animals (D a n i e l, 1964).

In some experiments rodents changed somewhat body weight (Table 7), what in many cases was coincided with the nitrogen balance (Table 6). Probably the drop in body weight resulted from the negative nitrogen balance. This happened in common and bank voles fed with bulky food, also in stripped field mice on both diets, and in yellow-necked field mice fed with acorns. A negligible drop in body weight in spite of positive nitrogen balance was noted also in yellow-necked field mice. In bank voles fed with mixed diet slightly negative nitrogen balance was found, however animals did not alter body weight.

In order to calculate real costs of maintenance, there were introduced corrections for any changes in body weight during the experiment. These fluctuations might result from growth or decrease both in fats and in protein, carbohydrates, mineral compounds, water, and alimentary tract content. During spells of insufficient feeding or starvation, or with feeding exceeding maintenance requirements, greatest changes one can, however, note in the quantity of fat tissue $(\mathrm{C} \mathrm{u} \mathrm{m}$ ming \& M orrison, 1960). This is why in all calculations of maintenance costs, with the drop in animal weight, there has been added an energetic equivalent for burned fat tissue at the value of $7 \mathrm{kcal} / \mathrm{g}$, accepted by $\mathrm{King}$ (1961). In the case of an increase in body weight, on the other hand, there was detracted the cost of fat deposition, which amount to circa $14 \mathrm{kcal}$ of metabolizable energy per $1 \mathrm{~g}$ of deposited fat (Kiela nowski, 1965). Most often fat comprises about $2 / 3$ of weight gain, the remainder falling to water and low caloric carbohydrates and protein (Konopinski, 1964; Blaxter, 1966). Therefore, per each gram of biomass increase there were detracted $9 \mathrm{kcal}$ So calculated corrections are negligible. Added or detracted from daily 
maintenance costs based on metabolizable energy, they mask differences formed as a result of various nutritional levels (Table 7).

In table 7 there was compiled daily energetic requirement in studied rodents. Maintenance costs in common voles amount on average to $0.577 \mathrm{kcal} / \mathrm{g} /$ day and are contained within limits of fluctuations of results obtained for these rodents with the aid of $R M R$ study, carried out also at the temperature of $20^{\circ} \mathrm{C}$. Results obtained with the aid of this method by various authors and in various seasons fluctuate from 0.405 up to $0.602 \mathrm{kcal} / \mathrm{g} /$ day (J ánský, 1959; S mirnov, 1960; M okriyewich, 1966; Grodziński, 1967; Trojan \& Wojciec how sk a, 1968).

Daily maintenance costs in voles with maintenance feeding were determined on an average for four diets on $0.512 \mathrm{kcal} / \mathrm{g} /$ day (Table 7). On the other hand results obtained from studies on oxygen consumption fluctuate from 0.336 up to $0.618 \mathrm{kcal} / \mathrm{g} /$ day (Grodziński, 1961; Smirnov, 1962; Visinescu, 1965; B ashenina, 1966; Górecki, 1966). Daily requirement of stripped field mice was evaluated from metabolizable energy on $0.701 \mathrm{kcal} / \mathrm{g} /$ day, while that evaluated from oxygen consumption - on 0.517 and $0.519 \mathrm{kcal} / \mathrm{g} /$ day $(\mathrm{Gr}$ o d z i nski, l.c.; S mirnov, 1960). Yellow-necked field mice in metabolic cages consumed on average $0.485 \mathrm{kcal} / \mathrm{g} /$ day of metabolizable energy. On the other hand results for these animals obtained in respirometers fluctuated from 0.277 to $0.507 \mathrm{kcal} / \mathrm{g} /$ day (K a l a b u k hov, 1953; G r od z ińs k i, 1961; G ę b c z yński, 1966).

Cited values of maintenance costs for small rodents calculated from oxygen consumption characterize themselves with a very broad amplitude. Results based on the techniques of food rations are, as a rule, contained within ranges of respiration determinations. Maintenance costs for bank voles and yellow-necked field mice calculated from metabolizable energy of various diets are, however, higher, when compared with daily metabolism $(A D M R)$. Results obtained in the course of feeding of bank voles and mice with mixed diet are best suited for comparisons with respiration. On mixed diets rodents changed at least their body weights. The daily maintenance costs calculated from metabolizable energy of mixed diet exceed results of $A D M R$ by $11.5 \%$ for bank voles (Gór e cki, 1968), by $13.5 \%$ for common voles (G r od ziński, 1967), and by $22 \%$ in mice (G ębczyński, 1966). They are very close to values of resting metabolism $R M R$ (differences of the order of $1-3 \%$ ) measured also at the temperature of $20^{\circ} \mathrm{C}$ (G rodzinski, 1961; Górecki, 1966). This phenomenon cannot be explained only with cage size as suggested by Odu m et al. (1962), because metabolic cages had the area of $113 \mathrm{~cm}^{2}$ (D r o ż d $\dot{z}, 1968$ ), while metabolic chambers - 
almost $500 \mathrm{~cm}^{2}$. Important moment presents the fact that both in metabolic cages and in small cages for RMR measurements the examined rodents have no nest, while metabolic chambers for $A D M R$ are supplied with nesting houses. The lack of nest exposes rodents to considerable heat losses and forces them to raising their metabolism by more than $17 \%$ (Pearson, 1960 ) or by $24.7 \%$ (Grodziński, personal communication). Besides, in small cages wild rodents are more mobile and excited ( $\mathrm{Grodziński} \mathrm{\&} \mathrm{Górecki,} \mathrm{1967).} \mathrm{Thus}$ divergencies in maintenance costs in rodents calculated from metabolizable energy and respiration should be explained by nest effect, and to a lesser extent by activity also. When assumed that rodents staying singly in cages without nests raise their energetic expenses by some $20 \%$, then "corrected " by this value maintenance costs for bank voles, common voles, and mice are very similar to those calculated with $A D M R$ techniques (Table 7). They reach then on average - in common voles 0.462 , in bank voles 0.432 , in yellow-necked field mice 0.387 $\mathrm{kcal} / \mathrm{g} /$ day, while their $A D M R$ was determined on 0.466 ( $\mathrm{G} \mathrm{rodzi}$ ń$\mathrm{ski}, 1967$ ), $0.494 \mathrm{kcal} / \mathrm{g} /$ day (G ó re cki, 1968), and $0.388 \mathrm{kcal} / \mathrm{g} / \mathrm{day}$ (G ę b c z y ńs k i, 1966), respectively.

In ecological studied maintenance costs in rodents might be approached both on the way of the determination of gaseous exchange and from the utilization of metabolizable energy. Studying the respiration is more precise, but the techniques of food rations is more simple technically and apart of maintenance costs enables the determination of two very important parameters for the balance of energy flow, namely: digestibility and assimilation of foods. The techniques of food rations provides also possibility for the verification of respiration measurements.

Acknowledgements: I wish to express my thanks to Dr. W. Grodziński for many valuable comments during this work and critical reading of the manuscript.

\section{REFERENCES}

1. Associations of Official Agricultural Chemist, 1960: Official Methods of analysis. 9th ed. Washington, D. C.

2. Bashenina N. V., 1962: Ekologia obyknovennoj polevki. Izd. Mosk. Un-ta, 1-307. Moskva.

3. Bashenina N. V., 1966: O sezonnyh izmenenijah himičeskoj termoregulacji u polevok. Bjull. M.O.I.P., biol., 71, 3: $27-40$.

4. Blaxter K. L., 1966: Przemiany energetyczne u przeżuwaczy. PWRiL: 1378, Warszawa.

5. Brody S., 1945: Bioenergetics and growth. Reinhold Publ. Corp., 1-1023, New York.

6. Cumming M. C. \& Morris on S. D., 1960: The total metabolism of rats during fasting and refeeding. J. Physiol., 154: 219. 
7. Danie1 M., 1964: Temperature and humidity in the nest of Clethrionomys glareolus observed in continuous experiment. Acta Soc. Zool. Bohemosl., 38, 3: $278-279$.

8. Davis D. E. \& Golle y F. B., 1963: Principles in mammalogy. Reinhold Publ. Corp.: 1-335, New York.

9. Drożd ż A., 1963: Nornica ruda, Clethrionomys glareolus ( $\mathrm{S} \mathrm{chreber}, 1780$ ), jako nowe zwierzę laboratoryjne. Zwierz. Lab., 1: 86-102.

10. D ro żdż A., 1966: Food habits and food supply of rodents in the beech fo:est. Acta theriol., 11, 12: 363-384.

11. Drożdż A., 1967: Food preference, food digestibility and natural food supply of small rodents. [In: "Secondary productivity of terrestrial acosystems «, Ed. K. Petrusewicz]. 1: 323-330. Polish Sci. Publisher. Warszawa-Kraków.

12. Drożdż A., 1968: Badanie strawności i asymilacji pokarmów u gryzoni. Ekol. pol. B 14: 147-159.

13. G ębczyński M., 1966: The daily energy requirement of the yellow-necked field mouse in different seasons. Acta theriol., 11, 17: 391-398.

14. Golle y F. B., 1960: Energy dynamics of food chain of an old field community. Ecol Monogr., 30, 2: 187-206.

15. Golle y F. B., 1962: Mammals of Georgia. Univ. Ga. Press, 1-218. Athens.

16. Golle y F. B., 1967: Methods of measuring secondary productivity in terrestrial vertebrate populations. [In: "Secondary productivity of terrestral ecosystems«, Ed. K. Petrusewicz]. 1: 99-124. Polish Sci. Publisher. Warszawa-Kraków.

17. Górecki A., 1965: Kalorymetr w badaniach ekologicznych. Ekol. pol. B 11: $145-158$.

18. Górecki A., 1966: Metabolic acclimatization of bank voles to the laberatory conditions. Acta theriol., 11, 18: 399-407.

19. Górecki A., 1968: Metabolic rate and energy budget of bank vole. Acta theriol., 13, 20: $341-365$.

20. Górecki A. \& Gębczyńska Z., 1962: Food conditions for small rodents in a deciduous forest. Acta theriol., 6, 10: 275-295.

21. Grodziński W., 1961: Metabolism rate and bioenergetics of small rodents from the deciduous forest. Bull. Acad. Pol. Sci. Cl. II. 9, 12: 493-499.

22. Grodziński W., 1962: Influence of food upon the diurnal activity of small rodents. Symp. theriol.: 134-140. Publ. House C. A. Sci., Prague.

23. Grodziński W., 1966: Bioenergetics of small mammals from the Alaskan taiga forest. Lynx, 6: $51-55$.

24. Grodziński W., 1967: Daily metabolism rate and body size of common voles, Microtus arvalis (P a 11.). Small Mamal Newsletters, 1, 3: 5-6.

25. Grodziński W. \& Górecki A., 1967: Daily energy budgets of small rodents. [In: "Secondary productivity of terrestrial ecosystems", Ed. K. Fetrusewicz], 1: 295-314. Polish Sci. Publisher. Warszawa-Kraków.

26. Hawkins A. E. \& J e w e 11 P. A., 1962: Food consumption and energy cequirements of captive British shrews and the mole. Proc. zool. Soc. Lord., 138: $137-155$.

27. Holišova V., 1960: Potrava myśice křovinně Apodemus sylvaticus L. na Ceskomoravske Vrchovině. Folia zool., 9, 2: 135-158. Brno.

28. Holišova V., 1967: The food of Apodemus agrarius (P a 11.). Zool. Listy, 16, 1: $1-14$. 
29. Jánský L., 1959: Working oxygen consumption in two species of wild rodents (Microtus arvalis, Clethrionomys glareolus). Physiol. bohemosl., 7, 5: 427 -478 .

30. Kaczmarski F., 1966: Bioenergetics of pregnancy and lactation in the bank vole. Acta theriol., 11, 19: 409-417.

31. K a la bukhov N. I., 1953: Sezonnye izmenenija reakcii želtogorlyh myšej na vozdejstvie uslovij sredy. Bjull. M. O. I. P. biol., 8, 3: 1-23.

32. Kaźmierczakowa R., 1966: Ecology and production of beech forest ground flora in the Ojców National Park. Studia Naturae, 1, 1: 95-114.

33. Kielanowski J., 1965: Estimates of the energy cost of protein deposit. ion in growing animals. [In: "Energy Metabolism». Ed. K. L. B laxter]: 13-20. Acad. Press. London-New York.

34. K ing J. R., 1961: The bioenergetics of vernal premigratory fat deposition in the white-crowned sparrow. Condor, 63: 128-142.

35. Kleiber M., 1961: The fire of life, pp. 1-454. John Wiley, New York.

36. Konopiński T., 1964: Żywienie zwierząt. PWRiL: 1-801. Warszawa.

37. Kostelecka-Myrcha A. \& Myrcha A., 1964: The rate of passage of foodstuffs through the alimentary tract of certain Microtidae under laboratory conditions. Acta theriol., 9, 4: 37-53.

38. K oškina T., 1957: Sravnitelnaja ekologia ryžih polevok v severnoj tajge. Materiały po Gryzunam., 5: 3-65, Moskva.

39. K učeruk V. V., 1963: Vozdeistve travojadnyh mlekopitajuščih na produktivnost travostoja stepi $\mathrm{i}$ ih značenie $\mathrm{v}$ obrazovanii organičeskoj časti stepnyh počv. Tr. Mosk. Obšč. Isp. Prir., 10: 157-191.

40. La ne-Petter W., 1957: Animal house equipment. [In: »The UFAW Handbook. The care and management of laboratory animals«. Edts.: A. N. W o rden \& Lane-Petter]: 28-45.

41. Mokriyevich N. A., 1966: Ecologico-physiological pecularities of common voles (Microtus arvalis $\mathrm{Pa}$ 11.) and house mise (Mus musculus L.) in Volga-Ural sands. Zool. Žurn., 45, 3: 447-451.

42. Morrison P. R. \& Teitz W. J., 1953: Observations on food consumption and preference in four Alaskan mammals. Arctic, 6, 1: 52-57.

43. M y r ha A., 1964: Variations in the length and weight of the alimentary tract of Clethrionomys glareolus ( $\mathrm{S} \mathrm{chreber}$, 1780). Acta theriol., 9, 10: $139-148$.

44. Myrcha A., 1965: Length and weight of the alimentary tract of Apodemus flavicollis (M elchior, 1834). Acta theriol., 10, 16: 233-236.

45. N a umov N. P., 1948: Očerki sravnitelnoj ekologii myševidnyh gryzunov. Izd. Akad. Nauk SSSR: 1-204. Moskva.

46. Nehring K., 1959: Ogólne żywienie zwierząt. PWRiL: 1-574. Warszawa.

47. Nehring K., Schiemann R., Hoffmann L., Klippel W. \& Jentsch W., 1965: Utilization of the energy of concentrates in relation to their nutrient composition. [In »Energy Metabolism«, Ed. K. L. B la x te r]: 243-268. Acad. Press. London-New York.

48. Nijkamp H. J., 1965: Some remarks about determination of the heat of combustion and the carbon content of urine. [In "Energy Metabolism», Ed. K. L. B la xter]: 147-158. Acad. Press. London-New York.

49. Odum E. P., Connel1 C. E. \& Davenport L. B., 1962: Population energy flow of old-field ecosystems. Ecology, 43, 1: 88-96. 
50. Pears on O. P., 1960: The oxygen consumption and bioenergetics of harvest mice. Physiol. Zoöl., 33, 2: 152-160.

51. Petrov O. V., 1963: Pitanije myševidnyh gryzunov lesostepnyh dubrav v laboratornyh uslovijah. Vopr. Ekol. Biocenol., 8: 119-173. Leningrad.

52. Petrusewicz K., 1967: Concepts in studies on the secondary productivity of terrestrial ecosystems. [In »Secondary productivity of terrestrial ecosystems «, Ed. K. Petrusewicz] 1: 17-50. Polish Sci. Publisher, Warszawa-Kraków.

53. R a jchel R., 1965: Net primary productivity of the herb layer in two forest associations of the Ojców National Park (Southern Poland). Fragm. Flor. Geobot., 11, 1: 121-150. Kraków.

54. R a fes P. M., Linesmann L. G. \& Pere1 T. S., 1964: Životnyj mir kak komponent lesnevo biogeocenoza. [In »Osnowy lesnoj biocenologii «, Edts: V. Sukachev \& N. Dylis]: 216-299. "Nauka", Moskva.

55. Ryszkowski L. \& Petrusewicz K., 1967: Estimation of energy flow through small rodent population. [In "Secondary productivity of terrestrial ecosystems«, Ed. K. Petrusewicz] 1: 125-146. Polish Sci. Publisher, Warszawa-Kraków.

56. Smirnov P. N., 1960: K voprosu o fizjologičeskih osobennostjah polevoj myši v svjazi s ee ekologiej. Tr. Peterg. In-ta LGU, 18: 202-214.

57. Smirnov P. K., 1962: Nekotorye ekologo-fizjologičeskije osobennosti evropejskoj zemlianej polevki. Vest. Leningr. Univ., Biol. 21, 4: 72-85.

58. Sviridenko P. A., 1940: Pitanije myševidnyh gryzunov i značenie eih v probleme vozobnovlenia lesa. Zool. Žurn., 19: 680-703.

59. Tanton T. M., 1965: Acorn destruction potential of small mammals and birds in British woodlands. Quart. Forestry, 59, 3: 230-234.

60. Trojan P. \& Wojciechowska B., 1968: Resting metabolism rate in european common vole, Microtus arvalis (P a 11.), in different ambient temperatures, Ekol. pol. A. 15, 43: 803-810.

61. Trela S., 1964: Wpływ implantacji stilbestrolu na bilans azotu, wapnia, fosforu i przemianę energetyczną u szczurów. Zesz. Probl. Post. Nauk Roln., 54: $7-21$.

62. Turček F. T., 1956: Quantitative experiment on the consumption of tree seeds by mice of the species Apodemus flavicollis. Arch. Soc. "Vanamo« 10, 1: 50 - 59. Helsinki.

63. Turček F. J., 1957: Konzumcia lesnýh semien myšou žltohrdlou (Apodemus flavicollis) a možnost ochrany semien a semenáčkov. Pr. vysk. ust. lesn. CSR 12: $251-303$.

64. Turček F. J., 1967: Cycling of some forest tree-seeds, with special reference to small mammals and then animals in general. [In "Secondary productivity of terrestrial ecosystems«, Ed. K. Petrusewicz], 1: 349-355. Polish Sci. Publ. Warszawa-Kraków.

65. Visinescu N., 1965: Researches on nicthermeral and seasonal variations of energetics metabolism in Clethrionomys glareolus and Apodemus sylvaticus. Rev. Rum. Biol. - Zool. 10, 3: 183-189.

66. Vor ontsov N. N., 1967: Evolucija piščevaritelnoj sistemy gryzunov. „Nauka«: $1-235$. Novosibirsk.

Received, April 16, 1968.

Department of Animal Genetics and Organic Evolution,

Jagiellonian University,

Kraków, 2, Krupnicza 50, Poland. 


\section{Andrzej DROŻDŻ}

\section{STRAWNOSC I ASYMILACJA NATURALNYCH POKARMOW U DROBNYCH GRYZONI}

\section{Streszczenie}

Zbadano konsumpcję naturalnych polsarmów, ich strawność i poziom asymilacji, a także dobowe zapotrzebowanie energetyczne $u$ czterech gatunków drobnych gryzoni. Obiekt tych studiów stanowiły: polniki zwyczajne, Microtus arvalis (P a 1las, 1779), nornice rude, Clethrionomys glareolus (S chreber, 1780), myszy polne, Apodemus agrarius ( $\mathrm{P}$ a $11 \mathrm{as}$, 1771) i myszy leśne, Apodemus flavicollis (M e lchior, 1834). Ogółem przebadano 11 diet treściwych, mieszanych i objętościowych, używając do każdej serii 10-15 dorosłych zwierząt (lącznie 120 gryzoni). Doświadczenia wykonywano w klatkach metabolicznych metodą bilansową, która polega na codziennym podawaniu zwierzętom znanej ilości paszy i kolekcjonowaniu całego kału i moczu. Próbki pasz, kału i moczu poddano standardowej analizie chemicznej, a ich wartość kaloryczną określono w kalorymetrze (Tabele 1,2$)$.

1. Wartości kaloryezne pasz były bardzo zróżnicowane od 4.159 do $8.032 \mathrm{kcal} / \mathrm{g}$ suchej masy bez popiołu, kału natomiast od 4.690 do $5.486 \mathrm{kcal} / \mathrm{g}$. Wartość kaloryczna $1 \mathrm{~g}$ płynnego moczu zamykała się w granicach $48-331$ cal. (Tabela 2).

2. Współezynniki strawności poszczególnych składników paszy (białka, tłuszezu i włókna) oscylowały najczęściej pomiędzy $70-90 \%$ (Tabela 3). Współczynniki strawności suchej masy przy paszach treściwych (bukiew, żolędzie, orzechy laskowe, owies) osiagaly od 84,3 do $93,5 \%$, a przy paszach mieszanych (orzechy laskowe i rośliny runa) od 80,9 do $85,5 \%$. Strawność suchej masy pasz objętościowych u nornic i polników była niższa i wynosiła średnio $73,9 \%$ (Tabela 3).

3. Straty energetyczne $w$ kale w stosunku do pobranej energii $w$ pokarmie wahaly się od 7,1 do $22,6 \%$, a w moczu od 0,7 do $5,4 \%$ w zależności od diety. Poziom asymilacji różnych pokarmów zamykał się więc w granicach od 65,2 do $90,9^{\%}$ energii pobranej $\mathrm{z}$ pokarmem. Przeciętnie polniki asymilowały $77,5^{\circ} \%$ pobranej energii, nornice blisko $83 \%$, myszy leśne $86,1 \%$, natomiast myszy polne aż $88,9 \%$ (Tabela 4, Fig. 1).

4. Nornice, polniki i myszy pobieraly dziennie w paszy od 12,7 do $16,2 \mathrm{kcal}$, natomiast asymilowały od 9,8 do $14,8 \mathrm{kcal}$ (Tabela 5). Rozpiętość taka jest funkcją wielkości ciała gryzoni, zależy także od rodzaju i wartości kalorycznej pasz.

5. Dorosły, nie rosnący gryzoń, o ciężarze ciała $25 \mathrm{~g}$ pobierał dziennie w paszy średnio $0,06 \mathrm{~g} \mathrm{~N}, \mathrm{z}$ czego wydalał w kale $0,01 \mathrm{~g}$, natomiast w moczu $0,05 \mathrm{~g} \mathrm{~N}$.

6. Dobowe zaopatrzenie energetyczne obliczone $\mathrm{z}$ zasymilowanego pokarmu wynosiło u nornic $0,432 \mathrm{kcal} / \mathrm{g} /$ dobę, u polników $0,462 \mathrm{kcal} / \mathrm{g} / \mathrm{dobę,} \mathrm{u} \mathrm{myszy} \mathrm{pol-}$ nych $0,561 \mathrm{kcal} / \mathrm{g} /$ dobę i u myszy leśnych $0,387 \mathrm{kcal} / \mathrm{g} /$ dobę. Wartości te są bardzo zbliżone do określonego $\mathrm{w}$ respiracyjnych pomiarach tzw. średniego metabolizmu dobowego (ADMR) (Tabela 7). 